\title{
Local Governance Units as a Public Manager in Albania
}

\section{Aurora Ndreu, MA LL.M PhDc}

\author{
European University of Tirana/Faculty of Law; Email: n.aurora@yahoo.com
}

\section{Doi:10.5901/mjss.2016.v7n3s1p465}

\begin{abstract}
When studying the public management, the top element doing this management in the public sector is the local government. $A$ better management by the local governance can give better public services to the citizens. As the first step on giving the best model of local governance managing public services, we should see how this functioned before, the problems relating to it and the focal points of it. We collect basic law literature and facts from everyday life regarding the management, how it was done and why it failed on giving an efficient public service by the local government. This is done by comparing this management on different periods and comparing the results of them. The result is that local governance has not function well as a public manager in Albania. Things can be improved by taking the steps and making the changes resulting from our study. In this paper I will show how the public management its done by the local government units in Albania after '90, the pro and contra of the system, the disbalance through the units regarding the management of public funds and those on collecting taxes and the recommendations on improving the management.
\end{abstract}

Keywords: Public management, local governance unit, Albania, Decentralization.

\section{Introduction}

According to the Local Government Law (2000), Article 9, the functions of the municipality, commune and county are divided into exclusive, shared and delegated. These functions define the role of the local units as public managers. The problem is how did the local government fulfill this role, to what extent and how this will be implemented now due to the new law on local self-government of 2015. This because the new law gives to the local self-government units more functions and responsibilities. But how it does local government function as a public manager of local services in Albania due to these abovementioned functions?

Local government itself is the people's right that takes part within a given territory, to govern their affairs independently and through bodies which they themselves choose within that territory. This independently governance is achieved on the basis of decentralization or local autonomy. Therefore, this principle takes priority in the existence of good practice in local government. The functioning and organization of local governance depends on the legislation of the country and as provided in the constitution. Also the relationship with central government agencies depend on the constitutional meaning.

Albania is a unitary state since creation. The jurisprudence recognizes the unitary and federal states. The federal states have typically two-level system of governance, governance in middle / first federal level and in the federal state government as second-tier governance. Such countries are Germany, Switzerland. The unitary states, as it is our country, have a central government which determines the general policy of development of the country. The simplest definition of local government is that this kind of governance is an institutional and legal organization such that ensures that people within a given territory act collectively to ensure their welfare.

Local governments need to happen when people live in a community and sufficiently close interaction (Crawford, 1999; 15) and to solve their problems they must work together as a group in order to achieve the results they want. Two basic elements that can be distinguished in this government are: management of services and representation of citizens. These elements are not only distinctive element of local government but also serve as an indicator of the effectiveness of such a government. The problem lies in determining which of these elements is more important or more developed? This has changed from time to time or from place to place. Nowadays I am convinced that we can not put in discussion the representation element, as this element has long been implemented and has fallen ground. Today in our studies can talk about times where democratic governance elements are the basis for the foundation of a state. At this point the problem remains to determine how the function of providing services was due to efficiency.

We should not forget that these local institutions are not only to provide various public services to citizens, but also to represent in the best way possible will of the people (Tindal, 1977: 3). Finally, the question of why there should be local government respond to the simple reason of providing various public services to citizens and ensure the representation of 
the will of the people.

Every part of the territory is administered by a Municipal government and all states within their territory, recognize and accept a set of values and principles on which is based local democracy.( Local government Law (2000) But the big problem of urban areas, it remains how to be structured and how to relate different levels of organization while meeting the functional needs in the best manner possible.

We must distinguish between regional self-government and regional autonomy. The latter is a more powerful form, close to classical federalism than local self-government, which then brings a greater impact in the constitutional structure within the state.

Local autonomy is a term that includes steadily the academic and popular discussion about the local government, but is rarely defined by conceptual meaning or become the subject of an empirical research.

Local autonomy can be defined as decentralization, as local fiscal discretion or as an adjustment to "home-rule" to do or define your own rules within "your own house".

The objective of local government is to provide a government as good at the local level by being closer to citizens, recognizing and accepting the existence of values and different identities within different communities, through respect for the rights and freedoms of citizens. This objective is achieved through the effective exercise of the functions of local government itself or services through the implementation of appropriate forms and above all promoting participation of community members in decision making.

The relationship between central and local government is based on the principle of subsidiarity ${ }^{1}$ and cooperation between them. To achieve a successful governance is needed this kind of cooperation in order to meet the best needs of the citizens.

\section{The Exclusive Functions of Local Government on Fulfilling the Public Management Purpose}

The exclusive funactions are called those functions that are provided by the local government law, for which it has complete freedom of authority and the necessary tools to use, in performing of such functions. Local government has full responsibility and must exercise its space within the legal norms and standards of best practices. The principle of selfgovernance of these units its based on these upsaid functions, meaning that the local government units are independently governed from the state agencies and national government.

The local government law (Local government law (2000), article 10, stipulates that municipalities and other local units have full administrative, service, investment and regulatory functions as stipulated by this article.

These functions of the local government are implemented always by respecting national policies set by the central government. This means that the central government can set standards which are floor level and must not be exceeded in their violation. On the other hand the respect of these standards does not mean that the central government should violate the autonomy of local government and in such cases where a municipality or other local unit is not able to realize the necessary revenue to meet the needs of the population within its territory, meaning not realizes investment, it will be assisted by the central government with its own funds.

\section{What are the Exclusive Functions of the Local Government Unit?}

According to Article 10 (Local government Law (2000), paragraph 3, these functions are divided as follows:

- Functions relating to infrastructure or public services

These functions are drinking water supply, sewage functioning of waters, sewage and protective channels of residential areas, construction, rehabilitation and maintenance of local roads, sidewalks and squares public lighting, public areas, urban public transport, the management of cemeteries and guarantee of the service, the service of decoration and cleaning of the territory, collection and disposal of waste, management of public parks and green areas, urban planning and territory management.

These functions are laid down also in the new law on local self-government (Local self-government Law (2015), adding other functions as construction and rehabilitation of schools, excluding the professional schools which will be managed by the national agency. This function till recently regarded to the national government, meaning the Ministry of Education represented in these local areas by the Regional Directory of Education. These directories had the investment office within, which was representative of the various investment projects. Also this office was acting as a superviser of the local unit investments regarding the education buildings, schools or nurseries granted by Ministry of Education. Also

${ }^{1}$ European Charter of Local Self-government (1999) 
with the new local self-government law there were added new responsibilities regarding to the administration of the kindergartens and daycare centers, which before were under the supervision of the national agencies.

\section{- Functions relating to social and cultural services}

Services of a social, cultural or sportive one, such as preservation and development of cultural and historical values of the area where the local unit is located, organization of sporting activities and administration of institutions that offer these services, social service and management of various institutions that provide services such as nurseries, shelters, orphanages are part of the local units functions.

The new law (Local self-government Law (2015) provides for in Article 24, paragraph a), the construction and management of social housing and other centers that provide social services.

3- Services related to local economic development such as preparation of local economic development programs, establishment and management of various public markets, small business development and promotion of the business, the establishment of the necessary infrastructure related to local economic development. These functions are performed by different departments and structures at municipality level and other collaborations with the business associations.

Article 28 of Law 139/2015 (Local self-government Law (2015) also provides for financial grants given from the local unit agencies to promote the small bussines development.

Also now there have been new functions regarding the rural and forestry development and public pastures, biodiversity etc which there have not been proclaimed before as a function of the local unit. According to the new law, the municipalities are responsible for performing such functions as administration and rehabilitation of the drainage systems. Prior these functions were performed by the national agencies, through Ministry of Rural Development. This ministry had a local office in the local administrative units which performed these actions.

It takes an enourmos importance the transfer of the forests and pasture to the local government units administration. This because there have been many unfinished legal disputes before regarding these problems of property.

\section{The Local Government Unit as a Public Manager of Water Supply}

Let's look closely at the problem of drinking water supply. The competent authority for such services was the water supply agency. During the transfer of more state property to local government units was presented a serious problem regarding the water supply dependence from central to local government. Besides the jurisdiction problem, the mere problem was that the latter were in a very vulnerable economic situation, such financial difficulties were as a result of the huge debts of Albanian Electro-Energy Corporation.

Mismanagement rule make that the incomes were very low and there was a large deficit between revenue and expenditure because of the not proper collection of the taxes. From January 2002, when it was planned that the aqueducts were transferred to local units, it began the problems, after it was determined the transfer of this service, because of non determining policies and the ways in practice it would be done this process. To fix such a problem, the government issued a Decision of the Council of Ministers no. 550 dating 07.11.2002, by which approved the policy document on decentralization of supply of drinking water and sewage. Through this document were identified for the first time transfer mode and procedures, how was managed water supply and what powers will the local units have. Only after the approval of this document it began the process of practical implementation of the law on the transfer of water supply to the local units respectively in 2004. (Hoxha \& Dhimitri, 2006)

While water supply was under the administration of the central government, their problems with financial insufficiency or debts were dealt with by the government through available funds. During and after being transferred under the administration of local units were brought many problems from the water supply management which were mostly in financial problems and could be not dealt with by local units due to lack of funds.

After 2004, the transfer of ownership process has been slow and has encountered many problems. Creation of the Company that would administrate water supply initially proved difficult and only a portion of the shares of these companies went to the local units, with time those aqueducts that had not major financial problems. It was the local unit which appointed the administrator by a decision of the local council. As regard this company would already have dependence on the local unit as the administrator was elected by the latter. New problems arose regarding jurisdictional conflicts between different local government units regarding their territories that will in turn link with each unit as cover.

These problems made state that through various subsidies help these new companies of water supplies through direct allocation of financial assistance. Despite this, it did not bring any improvement in the management of these companies and in many cases there were abuses because of complete lack of transparency in these subsidies. The best solution determined by the experts in this case was that the subsidy will be done through a few well-defined and 
transparent criteria in order to avoid the situations of abuse. So these criteria must be based on investments made in water supply, the solvency of the population within that territory, the occasional checks carried out, etc. (Beddies S., De Sotto H., Bakllamja A., et. (2004)

\section{Local Government as a Public Manager of Urban Planning}

The exercise of this function in practice has encountered problems as a result of jurisdictional conflicts between local government units regarding the right of granting building permits. Given that in many cases urban planning policies exceed the limits of a single local government unit but may include different units. In these cases it may be better addressed at the regional level which is made by the county (Qark). ${ }^{2}$

The local government bases its right on urban planning not only in its organic law (Local government Law, 2000) but also to a series of other important laws such as: Urban Planning Law (1998) as amended. Thus by Urban Planning Law (2003), the local government took on an important function which was already effective through the creation and functioning of the Territorial Adjustment Council in the local unit, which depended on the latter. Based on this competence, the local entities controlled and monitored the implementation of the legal framework concerning the construction within their area of jurisdiction but also there were the authorities that were giving permission for construction sites.

According to Article 2 of the law (Urban Planning Law 2003) amending Article 14 of Urban Planning Law (1998), there were specified organizations for urban planning at local government such as:

1- Territorial Adjustment Council of the communes / municipalities and counties

2- Department of the urban planning at the local unit composed by its director and the other specialists relevant to the department.

The Technical Council according to article 25 (Urban Planning Law, 1998) was a specialized body at the urban planning department of the municipality which functioned by the relevant bylaws. Members of this council were rewarded for the work performed and the remuneration was determined by the relevant local council unit.(Regulation of the local council) This technical committee should have in its composition specialist such as architects, engineers, lawyers etc.(The regulation of the Technical Council) Its members were assigned a part from a local council decision, and a part from the section or department of urban planning at the local unit. This council as long as it was in force was very important since all the different files or applications for building permits for sites were previously examined during its meetings.

These files were ready for approval to the Territorial Adjustment Council or were returned to the interested persons for the necessary amendments only after passing by legal and technical control of this council specialists. This latter council functioned as a decision-making body according to Article 16 (Urban Planning Law, 1998) in the regional councils, the Tirana Municipality and other municipalities that were first category cities. As chairman of this body the law (Urban Planning Law, 1998) determined the mayor or head of county council. These members were appointed by law, ex officio, with regard their number as well as their function as laid down in article 17 (Urban Planning Law, 1998).

Based on Article 20 of the same law (as amended), this body at the county council examines and approves the design plannings for various studies of urban areas including areas of more than one municipality or communes that fall within the territory of the region, also masterplans of different urban development district within its boundary. This mean that this body examined construction permits for outside the boundaries of villages but in the implementation of the approved master plans. As regard, this body included other territories except the municipality.

Due to the new changes made by the new law of 2014 (On the planning and development of the territory Law, 2014) as the responsible authorities for urban planning in municipalities according to Article 5, will be the council of the county at the regional level, and at the municipality level will be the municipal council along with the mayor. This law (Law on Planning and development of territory, 2014) on the Article 11 stipulates that the county council is responsible for coordinating and the planning processes at the regional level and to adopt the initiative or sectoral planning documents of the county. So the county preserves the role regarding the regional policy and the management due to such functions.

While municipal council according to article 12 is responsible for approving financial funds for the implementation of this law or urban planning documents, oversees the implementation of local regulatory plan and turns for completion and review the files that have deficiencies in documentation. This council plays the role of the superviser or controller regarding the decisions of the urban planning department and the mayor. As such this council serves as the last link of approval for construction permits.

\footnotetext{
2 The Albanian word used for it
} 


\section{Conclusion}

The process of privatization of many public services before granted by the local units, went into a difficult and overlong period.

The new law of 2014 determined in not very detailed way as laid down in article 14, that the local units should appoint bodies responsible for performing functions related to urban planning and development control of the territory, according to the legislation stated in the law, without detailing who will be these bodies and how they will function.

For the first time by this law (Planning and development of territory Law, 2014) in article 29 stipulates that all power over the approval of construction sites or building permits goes to a single individual that is the mayor. Article 29 states that the person responsible for taking decisions about applications for construction permits associated with the development or construction within the administrative territory of the municipality will be exclusively the mayor. Moreover, he will be the person responsible who will determine whether the proceedings are conducted in compliance with the preliminary statement for execution of works. Also he is also responsible for issuing the certificate of use for those building permits granted by him. A lot of power in the one man hands is not the perfect kind of democracy we are looking for nowdays.

According to the western way of offering the public services, maybe it should be necessary these be offered by private sector, but in Albania its too early this to happen. The people and the local units too are not prepared for such changes.

\section{References}

The Parliament of Albania, Law no 8405/1998 (1998)“ Urban planning Law”(1998) Retrieved March 1, 2016 from http://80.78.70.231/pls/ kuv/f?p=201:Ligj:8405:17.09.1998

The Parliament of Albania, Law no 8991/2003 (2003) "Urban planning Law" (2003) Retrieved March 1, 2016 from http://80.78.70. 231/pls/kuv/f?p=201:Ligj:107/2014:31.07.2014

The Parliament of Albania, Law no 107/2014 (2014) “Law on Planning and development of the territory" (2014) Retrieved February 20, 2016 from http://80.78.70.231/pls/kuv/f?p=201:Ligj:107/2014:31.07.2014

The Parliament of Albania, Law no 8652/2000 (2000) "Local government law"(2000) Retrieved February 20, 2016 from http://80.78.70. 231/pls/kuv/f?p=201:Ligj:8652:31.07.2000

The Parliament of Albania, Law no 139/2015 (2015)“Local self-government law" (2015) Retrieved February 20,2016 from http://www.ceshtjetvendore.gov.al/files/userfiles/LIGJI_139_2015_PER_VETEQEVERISJEN_VENDORE1.pdf

Hoxha, A., Dhimitri, A. (2006, November). Questionnare on the Implementation of the National Work Programmes for better local government, Second Regional Ministerial Conference on the Effective Democratic Governance.

Beddies S., De Sotto H., Bakllamja A., Chaurot de Beauchene X., (2004, December). Decentralization and water sector privatization in Albania, Retrieved November 2015, from http://siteresources.worldbank.org//

The Regulation of the Technical Council at the Urban Planning Department of Municipality

Crawford A., (1999, October 28) The local governance of crime: Appeals to community and partnerships, ISBN-13: 978-0198298458

Tindal C. R.,(1977) Structural changes in local government: Government for urban regions (Monographs on Canadian urban government) 